\title{
"LA OMS DISEÑA UN PLAN DE ACCIÓN PARA COMBATIR EL ABUSO DE ANTIBIÓTICOS"
}

DPA

El Comercio, 25 de mayo de 2015

http://www.elcomercio.com/tendencias/oms-antibioticos-medicina-medicamentos-infecciones.html

La OMS acordó un plan para combatir la resistencia a los antibióticos.

\section{Sus componentes}

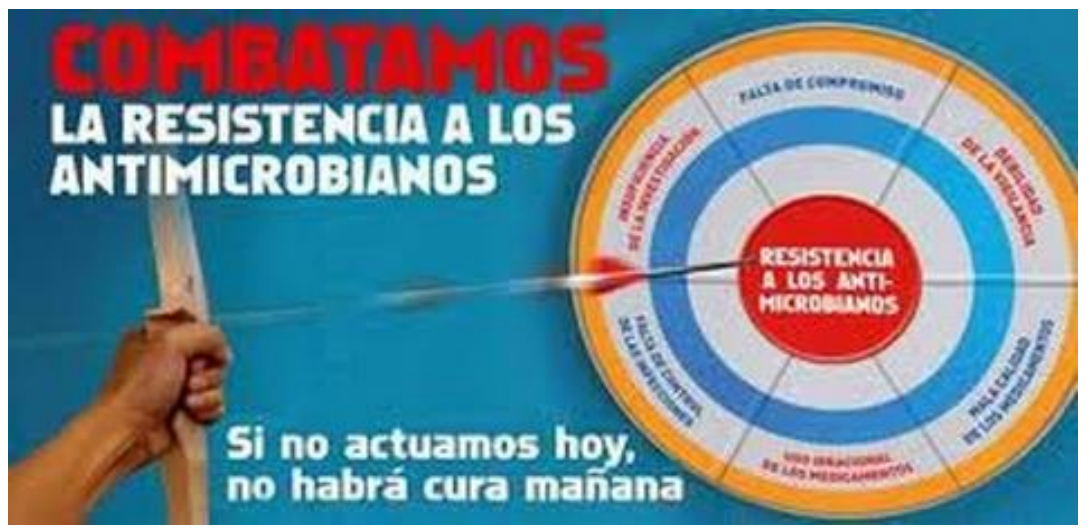

http://www.radiorebelde.cu/images/images/ciencia/dia-mundial-salud-2011.jpg

Las propuestas están orientadas a:

Mejorar la higiene hospitalaria.

Fortalecer la formación de médicos y veterinarios.

Mejorar el diagnóstico de la infección.

(to Prohibir la venta libre.

Estimular el estudio de nuevas moléculas.

Estudiar los gérmenes multirresistentes.

\section{No olvidar}

"Según la OMS, unas 700000 personas mueren cada año a consecuencia de la resistencia desarrollada por las bacterias a los antibióticos. Los antibióticos revolucionaron la lucha contra las enfermedades bacterianas, que antes de su descubrimiento con frecuencia eran mortales. Sin embargo, su uso abusivo, y en muchos casos inadecuado, llevó a que las bacterias y otros microorganismos desarrollaran una resistencia cada vez mayor a los antibióticos, como es el caso de la penicilina. Por eso, el efecto de estos medicamentos es cada vez menor y en casos extremos, nulo". 